Rev. Latinoam. Psicopat. Fund., São Paulo, 18(1), 17-32 mar.2015

http://dx.doi.org/10.1590/1415-4714.2015v18n1p17.2

\title{
Conferência
}

\section{Que saúde esperar ao final de uma análise?*1}

\author{
Tania Coelho dos Santos*2
}

Para Freud, a neurose consiste em responder aos acontecimentos da vida de forma incapacitante, diferentemente da resposta do homem sadio que os ultrapassa. Que saúde poderíamos esperar, então, ao final de uma análise? Um analista não poderia prometer mais do que a substituição da miséria neurótica pela infelicidade comum, banal, cotidiana? Freud advoga que o que se alcança por meio de uma análise não é o sintoma sexual que o sujeito apresentava ao iniciá-la, e sim sua redução a um resto incurável. A análise produz um estado que nunca surge espontaneamente no ego e que esse estado recentemente criado constitui a diferença entre uma pessoa que foi analisada e outra que não foi.

Palavras-chave: Final de análise, resto incurável, estado original, saúde

${ }^{* 1}$ Conferência pronunciada no VI Congresso Internacional de Psicopatologia Fundamental, em Belo Horizonte, MG, setembro de 2014.

*2 Universidade Federal do Rio de Janeiro - UFRJ (Rio de Janeiro, RJ, Br). 
Certa vez, perguntaram a Freud sobre a diferença entre um homem neurótico e outro que passou por um tratamento analítico, ao que ele respondeu: - nenhuma. Veremos que não é tão simples assim. Primeiramente, considera que ser analisado significa assemelhar-se a qualquer outro homem sadio. Por quê? A neurose consiste em responder aos acontecimentos da vida de forma incapacitante, diferentemente da resposta do homem sadio que os ultrapassa. Quando removidas as barreiras da inibição, um neurótico se iguala aos seus contemporâneos. Que saúde nós poderíamos esperar, então, ao final de uma análise? Um analista não poderia prometer mais do que a substituição da miséria neurótica pela infelicidade comum, banal, cotidiana? Vejamos os argumentos em favor deste ponto de vista. Ao término de uma análise, o rochedo da castração se revela intransponível. Um homem não abre mão de sentir-se ameaçado de submissão a outro homem. A ameaça de castração ou o temor de ser privado do falo não é eliminável. Uma mulher, por sua vez, jamais abandona a reivindicação de receber alguma coisa equivalente ao falo que ela não tem. Podemos resumir os limites de uma análise assim. Nada de saúde sem o limite intransponível da diferença sexual! Deste pathos, nenhuma análise nos livraria em definitivo.

Vale recordar, entretanto, que algum tempo depois Freud reformula este ponto de vista. Advoga que o que se alcança por meio de uma análise não é o sintoma sexual que o sujeito apresentava ao iniciá-la, e sim sua redução a um resto incurável. Penso que Freud (1937/1976) sustenta alguma coisa que está mais de acordo com o ponto de vista que será adotado pelo psicanalista francês Jacques Lacan. Ser analisado é alcançar um estado original que não é a simples normalidade: "Não é precisamente a reivindicação de nossa teoria o fato de que a análise produz um estado que nunca surge espontaneamente no ego e que este estado recentemente criado constitui a diferença entre uma pessoa que foi analisada e outra que não o foi?" (p. 259). Seguindo os passos deste testamento freudiano acerca dos obstáculos ao final de análise, neste artigo que foi intitulado "Análise terminável e interminável", percebemos que é preciso dar um passo a mais se queremos compreender em que consiste a saúde que poderemos almejar. Freud ressalta que a defesa psíquica consiste primordialmente numa recusa de um fragmento da realidade, a castração, que permanece ativo e reivindica ser reconhecido. Este fragmento comporta-se 


\section{CONFERÊNCIA}

como um resto do funcionamento psíquico de uma época anterior que se mantém intacto numa época ulterior. O investimento psíquico nestes restos resiste a ser reduzido pela análise. Freud considera que uma análise termina quando o paciente não sofre mais de seus sintomas e ultrapassou suas angústias e inibições. O que implica em dissolver os restos. O fim da análise depende do destino dos resíduos de três causalidades distintas: dos efeitos do traumatismo, da força da pulsão e das alterações do eu em consequência das deformações introduzidas pelas defesas. Como o objeto sobre o qual incide o recalque originário não é representável, não haveria, entretanto, uma palavra conclusiva. Como então abordar o fim da análise sem a palavra final?

Para responder a esta pergunta, Freud distingue duas causas da neurose: o traumatismo e a pulsão. Se a neurose é causada por um encontro traumático, o eu não foi lesado e o fim da análise é possível. Mas, se a causa é a pulsão, o final da análise é problemático em consequência das alterações deformantes no eu, em sua capacidade de enfrentar as dificuldades da vida. No primeiro caso, acontece uma resposta imediata do eu que vai poupá-lo. No outro caso, a pulsão trabalha incessantemente no interior do psiquismo e, para defender-se, o eu se deforma: "Somente quando um caso é predominantemente traumático é que a análise alcançará sucesso em realizar aquilo que é tão superlativamente capaz de fazer (...)" (p. 252). Nestes casos, podemos "graças a ter fortalecido o eu do paciente substituir, por uma solução correta, a decisão inadequada tomada em sua vida primitiva" (p. 252). Somente nestes casos, ele afirma: "pode-se falar que uma análise foi definitivamente terminada" (p. 252). E o paciente não produzirá outro distúrbio que exija análise. Muito embora não se saiba até que ponto semelhante imunidade se deva ao destino bondoso que lhe poupou provações demasiadamente severas.

Porém, se pensamos a neurose em termos de uma desproporção constitucional entre a força da pulsão e o eu que não alcança submetê-la, obrigando-o a deformar-se de todas as maneiras possíveis, não se deve esperar uma solução analítica positiva. No que se refere, portanto, à divisão do sujeito no processo de defesa, trata-se de perceber como se deu, caso a caso, a coexistência de duas atitudes incompatíveis diante da castração: "Eu reconheço que não há e eu mantenho que há". Este princípio universal da defesa ante a castração responde a duas lógicas diferentes: a do trauma e a da pulsão. $O$ trauma não produz alteração do eu. Para salvar sua integridade, o eu simboliza, por meio do sinal de angústia, o perigo da castração. Quando o excesso pulsional não se inscreve por meio da simbolização da castração, o eu será invadido repetidamente pela angústia. Caberia abordar esta diferença nos termos da oposição entre saúde e doença? Para avançar esta questão vou confrontar duas abordagens do funcionamento psíquico.

Proponho que a abordagem freudiana da saúde psíquica apoia-se na hegemonia do aparelho simbólico sobre as pulsões. Esta hegemonia em sua 
primeira tópica do aparelho psíquico lhe parecia a consequência natural de uma abordagem evolucionista do organismo vivo que, acima de tudo, quer sobreviver. Por esta razão, submete a tendência primitiva a alucinar o objeto da satisfação pulsional, e a substitui pelo reencontro deste objeto na realidade exterior. Ser normal é ser saudável, isto é, ser capaz de trocar a satisfação alucinatória com um objeto inalcançável pela satisfação possível com os objetos que nos são oferecidos no mundo que nos cerca. A hegemonia do princípio do prazer na vida psíquica precisa submeter-se ao princípio de realidade. Ser normal é ser capaz de adaptar-se. Ser neurótico é permanecer fixado à modalidade infantil de satisfação pulsional, resistindo a sublimá-la e a encontrar satisfações mais adaptativas.

Esta concepção evolucionista da neurose, como efeito do traumatismo da castração, fracassa ante a descoberta da resistência do eu, da reação terapêutica negativa e do apego ao sintoma. São índices de que a aliança terapêutica com o psicanalista não triunfa sobre todas as neuroses. Freud é levado então a repensar sua teoria do aparelho psíquico. Precisou reconhecer que havia um princípio mais primitivo e mais pulsional que o princípio do prazer. Uma força obscura ergue-se mais além do princípio do prazer e rejeita abandonar os modos primitivos de satisfação. Essa força é antinatural, contrainstintiva e não hesita em colocar em risco o desejo de sobreviver. Vem ao primeiro plano, nesta época, a causalidade pulsional da neurose. $\mathrm{O}$ ideal de saúde, a expectativa de remissão dos sintomas e de cura das neuroses vão sofrer um rude golpe a partir de então. Podemos colocar a questão nos seguintes termos: que espécie é esta, a espécie humana, inimiga da seleção natural e da evolução das espécies? Estes achados clínicos foram ainda mais duramente questionados do que a descoberta do inconsciente e a hipótese da universalidade da sexualidade infantil como causa das neuroses. A psicanálise freudiana teria se tornado pessimista e não pode nos prometer um pouco mais de saúde ao final de uma análise?

Penso que, longe de nos legar uma teoria pessimista dos poderes de uma análise, Freud não recua diante do impasse que a nova descoberta lhe impõe. Recordo sua aposta em que "a análise produz um estado que nunca surge espontaneamente no ego e que este estado recentemente criado constitui a diferença entre uma pessoa que foi analisada e outra que não o foi" (Freud, 1937/1976, p. 259). Penso que para Freud, a dissolução da miséria neurótica em infelicidade cotidiana não nos deixa sonhar com um final de análise sem restos. Mas, podemos alcançar a promessa de novos começos. Questão que conduzirá o psicanalista francês, Jacques Lacan, a inventar o dispositivo do passe para investigar o que cada um inventa para se virar com a força da pulsão.

$\mathrm{O}$ que é ser analisado para Lacan? O dispositivo do passe, inventado por Lacan, foi um esforço de responder esta questão. O passe repousa numa posição acerca do caráter terminável de uma análise. O analisado, para Lacan, ex-siste. 


\section{CONFERÊNCIA}

Este caráter finito da experiência pode ser julgado por meio dos resultados que é capaz de produzir. Depois de Lacan, aprendemos a acreditar que o atravessamento do fantasma conduziria ao ultrapassamento do rochedo da castração. Mais além do impasse do falo como símbolo da diferença sexual, se revelaria o real sem sentido, impossível de representar. A queda das identificações às quais um sujeito [\$] teria se fixado e a dissolução das fixações [objeto $a$ ] onde o gozo estaria condensado, ao final da análise, levariam à emergência de um desejo inédito, o desejo do analista. Este desejo não está submetido ao retorno do sentido recalcado nas formações do inconsciente estruturado como a linguagem. Por isso uma análise não é interminável, esta é a aposta de Lacan.

A tese da continuidade entre o normal e o patológico, contestada no testamento de Freud, encontra com Lacan uma formalização mais precisa. Para Lacan, este "estado que nunca surge espontaneamente no eu, estado recentemente criado e que constitui a diferença entre uma pessoa que foi analisada e outra que não o foi (...).", parece-me que equivale ao conceito de "desejo do analista". O desejo do analista é um desejo de saber que emerge no lugar do amor transferencial ao saber suposto ao inconsciente. Este desejo inédito é real, funda-se no saber da pulsão. Neste registro, o sujeito sequer sabe que fala. Diferentemente do que acontece no circuito da demanda, a pulsão comparece onde o sujeito não fala.

De acordo com Miller (2000): “A análise, justamente permite descobrir este lugar - onde a falta-a-ser é uma falta em falar - , pelo contrário, fala embora não saiba disso" (p. 394). Se houve análise, o sujeito sabe que fala ao nível da pulsão. Para concluir, no primeiro ensino de Lacan, o desejo do analista é a única medida de saúde. Saúde em reconhecer e suportar o destino de não ser senão a mutação da pura falta-a-ser, neste silêncio que fala sem precisar de palavras. Trata-se de identificar-se a essa falta de um sentido último e de oferecer-se, eventualmente, a conduzir um outro analisando a reconhecer nela sua verdadeira e última realidade.

Podemos perceber que, se um desejo inédito como esse pode emergir ao final de uma análise, é porque o inconsciente não é apenas o retorno do recalcado. $\mathrm{O}$ inconsciente é também real. O inconsciente real é o nome lacaniano da pulsão de morte. Uma análise não trava apenas um embate com o sentido recalcado e a impossibilidade de representá-lo. Mas com "Um corpo" vivo marcado pelo significante, lugar de um real impossível de suportar. O inconsciente real é o modo singular de cada ser falante usufruir ou padecer de seu corpo, resto não eliminável pela interpretação do sentido que se extrai ao final de uma experiência analítica. O desafio do analista não é simplesmente o de decifrar o sentido que se oculta sob as formações do inconsciente. É preciso desalojar o gozo e converter a repetição dolorosa de um mesmo fracasso - deste real impossível de suportar — em uma nova aliança com a vida e com a satisfação. 
Lacan teria se convertido ao vitalismo ao final de seu ensino? Posso afirmar que o último ensino de Lacan desencoraja o diálogo com os estruturalismos lógicos, linguísticos, topológicos. Porém, nos convida a conversar com as definições de saúde tomadas de empréstimo às ciências da vida.

A linguagem identifica os termos saúde e valor. Valere em latim significa passar bem. O que é a saúde, segundo as ciências da vida? Destaco as seguintes definições. Primeiramente, uma das mais conhecidas, a de Réné Leriche (apud Canguilhem, 1994/2005): "A saúde é a vida no silêncio dos órgãos" (p. 35). Kant (apud Canguilhem, 1994/2005) tratou a questão da saúde na terceira seção de Conflito das faculdades. Encontramos a aproximação entre saúde e bem-estar: "O bem-estar não é sentido, pois é simples consciência de viver e só seu impedimento suscita a força de resistência" (p. 37). E ainda a de Goldstein que nos interessa mais, pois aproxima saúde e ordem: "Ser sadio é ser capaz de se comportar ordenadamente, e isso pode ocorrer apesar da impossibilidade de certas realizações que antes eram possíveis" (p. 156). Georges Canguilhem (1978, p. 158) esclarece que para Goldstein: "Ser sadio significa não apenas ser normal numa situação determinada, mas ser também normativo, nessa situação e em outras situações eventuais. $O$ que caracterizaria a saúde é a possibilidade de tolerar infrações à norma habitual e de instituir normas novas em situações novas". A tese de Canguilhem merece toda nossa consideração pois acredito que ela incide sobre este conceito psicanalítico tão adverso à ideia de saúde - que é a pulsão de morte. Ela é muito adequada ao conceito de corpo vivo marcado pelo significante Um. Ele afirma que ser sadio é não resistir à tentação de abusar por excesso ou omissão do próprio corpo. Abusar da saúde, pasmem vocês, faz parte da saúde. E, mais importante, reformulando Leriche, Canguilhem (1994/2005) avança que:

$\mathrm{O}$ homem sadio que se adapta silenciosamente às suas tarefas, que vive sua verdade de existência na liberdade relativa de suas escolhas, está presente na sociedade que o ignora. A saúde não é somente a vida no silêncio dos órgãos [como queria Leriche] é também a vida na discrição das relações sociais. (p. 44)

Parafraseando Jacques-Alain Miller (1987/1999), quanto mais discreta, mais tranquila e certa é a vida. A vida nunca sonhou conviver com a verdade. O saber em jogo no funcionamento natural dos corpos é apto a assegurar sua sobrevivência.

Bem, o corpo vivo, de acordo com Canguilhem (1994/2005), é, então, este existente singular cuja saúde exprime a qualidade dos poderes que o constituem, visto que deve viver sob a imposição de tarefas, portanto exposto a um meio ambiente que, em primeiro lugar, ele não tem escolha. $\mathrm{O}$ corpo humano vivo é o conjunto dos poderes de um existente tendo capacidade de avaliar e de se representar a si mesmo esses poderes, seu exercício e seus limites (p. 41). Acompanhando esta definição, como queria Nietzsche (1998), o corpo são fala com melhor boa-fé e mais pureza; o corpo 


\section{CONFERÊNCIA}

completo, o corpo cujos ângulos são retos fala do sentido da terra. Saúde é fiabilidade, retidão, completude: "O corpo é uma grande razão, uma multiplicidade com um único sentido, uma guerra e uma paz, um rebanho e um pastor" (p. 60). Prossegue assim: "Há mais razão em teu corpo do que em sua sabedoria. E por que o teu corpo, então, precisaria logo da tua melhor sabedoria?" (p. 60).

Traduzimos, por meio da aproximação com estas referências, o deslocamento que se produziu no pensamento de Lacan entre o inconsciente-interpretável e o inconsciente real. O corpo vivo, cabe esclarecer, é o existente solitário, Um-corpo marcado pelo significante, encerrado em sua maneira única de gozá-lo. A interpretação analítica contraria o autismo da solidão do corpo-significante. Podemos afirmar que, ao final de sua análise, um ser falante se aproxima de reconhecer o mais real em sua existência, como impossível de representar. Circunscreve-se o significante arbitrário no qual se enraíza o sinthoma ou a maneira singular de cada um usufruir de Um-corpo.

Em nossa prática, acreditamos que existe uma relação entre o sentido e o real por meio do sintoma. Se não fosse essa crença no sintoma, a operação analítica careceria de qualquer ancoragem legítima no real. A psicanálise se reduziria ao exercício de uma narratologia, nominalista ou pós-moderna no que se refere à relação entre o significante e o real. A prática psicanalítica, ao contrário, é realista. Seu realismo se ancora no fato de que as representações, os sentidos ou as verdades variam, mas o sintoma permanece - razão pela qual nós o consideramos, na nossa prática, como equivalente ao real.

Lacan promoveu o declínio da verdade por meio da lógica, reduzindo-a à letra $[\mathrm{V}]$. Na escrita, a verdade é encadeada aos axiomas, às regras de dedução, reduzindo-se a um saber dedicado a circunscrever o real. $O$ real não é a verdade, pois esta última é variável. O real é a certeza que se alcança pelo significante, pelo saber. As letras $\left[\mathrm{S}_{1}\right]$ e o objeto $[a]$ escrevem justamente a certeza do real, dessa identidade de si a si. O significante-unidade é fundamental, pois lalíngua se precipita na letra, na escrita, na cifração que engendra o sintoma a partir de algo do real que não cessa de se escrever: a pré-maturação, o desamparo e a morte.

E o que seria a letra? É unicamente o que nos abre o acesso ao real. É apenas por meio dela que captamos o que haveria de mais vivo ou de mais morto na linguagem. A letra é análoga ao gérmen porque sendo a letra aquilo que, do significante, se inscreve no corpo, ela é incorporada. A letra não é a individualidade somática de cada um. "A duração da letra se estende além da vida" (Miller, 1987/1999, p. 45). Em A terceira, Lacan se mostra surpreso com o fato de que algo de real, a própria vida, se estrutura como um nó. É também surpreendente, Lacan observa, que não exista na natureza (nem na anatomia, nem nas plantas trepadeiras) nenhuma imagem natural do nó. O DNA e a letra seriam homólogos em sua estrutura, estranhos ao campo da representação e idênticos ao real. O mais real é, 
portanto, o próprio nó entre o simbólico, o imaginário e o real. O nó é o sintoma. O sintoma é o que se transmite de uma geração à outra. O sintoma é análogo ao gérmen, ao gene, ao DNA que veicula a vida para além da morte do indivíduo.

Foi no Seminário XX, Mais ainda, que Lacan estabeleceu essa homologia curiosa entre a letra e o gérmen, que nos dá a chave dessa relação entre a vida e a estrutura do sintoma. Ela repercute em outra clave a distinção que Freud efetuou entre o germoplasma e o somatoplasma. Para Freud (1914/1976), o indivíduo seria atravessado pela divisão entre as pulsões de autoconservação — interessadas na sua sobrevivência - e as pulsões sexuais que veiculam o desejo imortal da espécie de crescer e se reproduzir, consagrando a vida do indivíduo à morte. A letra, o gérmen, o DNA e o nó do sintoma são os nomes lacanianos do real. Podemos esclarecer o último Lacan à luz do vitalismo e da moderna biologia molecular?

$\mathrm{O}$ vitalismo foi essencial à constituição da biologia como uma ciência da vida ao final do século XIX. Ele coloca a questão da natureza da vida e suas determinações em termos de força vital. $\mathrm{O}$ vitalismo é correlato do surgimento do conceito de vida, conceito que afirma um princípio irredutível ao domínio físicoquímico para explicar os fenômenos vitais. François Jacob (1983, pp. 299-300) advoga que a unidade físico-química no nível molecular foi reconhecida com o conceito de hereditariedade e o vitalismo perdeu inteiramente sua função.

24 Ele acredita que o conceito de vida perde seu valor operatório. Canguilhem, diferentemente, mostra que há no conhecimento da vida, fenômenos que a mantém distante dos processos físico-químicos e exigem abordar a doença, a morte, a monstruosidade, a anomalia e o erro. Para Foucault (2000), o vitalismo teve e continua tendo o papel de indicar que as ciências da vida não podem se abster de uma posição de valor. Tal posição é: "mais uma exigência do que um método, mais uma moral do que uma teoria” (p. 263). Jacob explica que o recurso a um princípio vital decorre da atitude da biologia, da necessidade de separar os seres das coisas e de fundar esta separação não na matéria, cuja unidade é reconhecida, mas nas forças. A vida é esta fração de desconhecido, que existe no animal ou na planta, que faz com que o organismo seja diferente da coisa, e a biologia da física.

Em Le concept et la vie, Canguilhem (1966) analisa a revolução na genética e na biologia molecular a partir do conceito de vida. Na segunda metade do século XX, a biologia se desloca do que é macroscópico em direção ao estudo da célula, da bactéria, do cromossoma, do gene e da enzima. Ela muda a escala em que são estudados os fenômenos da vida. Não é mais o corpo em sua totalidade que lhe interessa, mas a célula reprodutora. A biologia muda de linguagem. Em lugar das concepções geométricas da mecânica, da física e da química clássicas, ela adota a teoria da linguagem e a teoria da comunicação. Seus conceitos-chave são agora: mensagem, informação, programa, código e instrução. No século XX, a biologia vai às fontes da vida, buscando os funcionamentos fisiológicos e as doenças que 


\section{CONFERÊNCIA}

se incrustam no genoma. Parafraseando Dagonet (1977), a biologia orienta-se pelo movimento entrópico - pelo qual não cessamos de nos destruir, mas também nos renovamos. A vitalidade consiste em se autorregular. O corpo instaura normas, nele há uma margem de inventividade, a vida é a variação das formas e obedece às exigências do meio. A doença é aquilo que não suprime, mas, eventualmente, limita esta capacidade de invenção.

Pode causar uma certa desconfiança no leitor o fato de que eu tomo o caminho da filosofia da ciência, em particular, da biologia como ciência para abordar as consequências do último ensino de Lacan sobre o final de uma análise e a esperança de saúde que a psicanálise pode alimentar. Lacan não se refere a Canguilhem, mas podemos reconhecer a afinidade deste grande epistemólogo com a psicanálise se considerarmos, por exemplo, esta citação: "ser sujeito de conhecimento, se o $a$ priori está nas coisas, se o conceito está na vida, é simplesmente estar insatisfeito com o sentido encontrado. A subjetividade é apenas então a insatisfação. Mas isso talvez, é a própria vida" (Canguilhem, 1970, p. 223). A redução lógica do sintoma às letras $\left[\mathrm{S}_{1}\right]$ e $[a]$ revela que elas escrevem uma verdade [V]. Verdade de uma insatisfação vital chamada desejo. Com base em minha análise pessoal e em minha experiência clínica, advogo a tese de que esta verdade se demonstra, paradoxalmente, ao final de uma análise, por meio de uma inversão no contrário. Em lugar da incerteza e da insatisfação que incitam o desejo a relançar sua busca do objeto perdido, surge a certeza da satisfação de estar simplesmente vivo.

Em sua leitura do "Sonho da injeção em Irma", Lacan (1954-1955/1978) destaca que a resposta à questão sobre a causa da neurose surge com a fórmula enigmática de uma escrita fora do sentido: a palavra trimetilamina. Para além do campo da fala, esta escrita designa a causa do desejo como um real impossível de dizer.

Tal como um oráculo, a fórmula não fornece resposta alguma ao que quer que seja. Mas, a própria maneira pela qual ela se enuncia, seu caráter enigmático, hermético, é a resposta à questão do sentido do sonho. Pode-se calcá-la na fórmula islâmica: - Não há outro deus senão Deus. Não há outra palavra, outra solução do problema de vocês, senão a palavra. (p. 202)

A fala reduzida à letra é o nó do sintoma. O Nome-do-Pai, significante mestre e as espécies da Coisa (das Ding), o objeto a, quando reduzidos à letra, são equivalentes ao Real. Ao Nome-do-Pai como uma referência universal equivale ao real na neurose: impossível de representar e de suportar. O objeto a, em sua extimidade, pode indicar a via para o real como uma contingência vivificante.

Faço esta distinção para ressaltar o valor pulsional das fórmulas que enunciam um mandamento superegoico e que se referem à função do Nome-do-Pai. Penso que todas elas equivalem a variações de um mandamento incompleto: "bate-se...". Fórmula reduzida do enigmático fantasma fundamental — extraído por Freud 
da experiência da perversão — "bate-se numa criança”. Ao final de uma análise, é preciso encontrar um novo destino para esta dimensão pulsional da consciência moral: a voz do Outro que antecede o surgimento do sujeito. Esse "bate-se..." é a face de gozo em jogo na lei moral e, portanto, é equivalente ao "tu deves..." de que fala Kant.

As construções do fantasma fundamental são formações particulares, são versões do Nome-do-Pai, da lei moral universal. São variantes da máxima que Kant formulou em seus "Fundamentos da metafísica dos costumes": "Age sempre de tal forma que trate a humanidade tanto em tua pessoa quanto na pessoa de qualquer outro, sempre, ao mesmo tempo, como fim e nunca como meio" (apud Coelho dos Santos, 2010, pp. 193-194). Ao universal da lei, articula-se o real do gozo impossível. O gozo interditado pela lei moral que enuncia que ele é impossível toma a forma de uma verdade masoquista.

Incluo nessa categoria a fórmula do meu próprio fantasma fundamental: "não vender a alma para o diabo" (Coelho dos Santos, 2010, p. 152). A contrapartida deste imperativo é a exigência pulsional de dizer toda a verdade, nada mais que a verdade. A verdade, diz Lacan (1969-1970/1991), é a irmãzinha do gozo. O gozo masoquista com a insatisfação histérica abriga-se na fórmula que enuncia o mandamento superegoico. Quanto mais o sujeito reclama a transparência da verdade, mais recusa a satisfação com o corpo. A histérica, diz Lacan, precisa apontar que o mestre é barrado. Para que serve evidenciar a castração do mestre? Para não consentir em ocupar o lugar do objeto $a$, causa do desejo.

Essa estrutura significante resume toda a minha neurose: "não venda a alma para o diabo". Ela abre-se para uma multiplicidade de recordações, repetições e elaborações. Sobre esta injunção, posso dizer que se trata de uma espécie de nome de família. Ela me insere na linhagem, no contexto ou na lalíngua familiar. Para resumir, esta estrutura significante é uma interpretação particular da lei edipiana que interdita o gozo. O grande Outro da família me antecede, cifrando o desejo e o gozo por meio desta injunção enigmática. Injunção que alimenta o gozo histérico com o sintoma da insatisfação. A histeria consiste na recusa do gozo em benefício do significante. A insatisfação feminina, tal como Freud a elucidou, nada mais é do que a versão feminina do rochedo da castração: penisneid. Razão pela qual as histéricas são desejantes e insatisfeitas por excelência.

Passo a elucidar o ultrapassamento deste impasse que releva do par gozo interditado/desejo insatisfeito. Procuro apresentar ao leitor minha própria versão acerca da natureza deste "estado original que nunca surge espontaneamente no eu" de que fala Freud. Penso demonstrar assim, de que saúde se trata ao final de uma análise. Um sonho repetitivo revela a outra face do desejo insatisfeito: o gozo silencioso e masoquista que se manifesta diretamente na experiência de angústia como pura divisão subjetiva. Passo a demonstrar como o ultrapassamento da 


\section{CONFERÊNCIA}

angústia, ao final da análise, pode dar lugar ao gozo com a letra fora do sentido. Para além do enredo edipiano e das ficções da castração que se escrevem por meio das letras $\left[\mathrm{S}_{1}\right]$ e $[a]$, surge uma dimensão inédita de lalíngua, o continente negro da feminilidade, que Lacan formalizou por meio do matema $[S(\mathbb{A})$ ]. Esta manifestação do inconsciente real, extremamente singular, pode ser decifrada por meio da homofonia da letra fora do sentido.

Neste sonho repetitivo que passo a relatar, sou jogada pelas ondas do mar que se levantam de ambos os lados. Encontro-me entre dois mares. Debato-me angustiadamente entre as ondas do mar, não posso correr, fugir delas em direção à praia. Não existe praia alguma. Este sonho angustiante foi durante muitos anos de análise insensível às interpretações pela via do sentido edipiano que buscavam remetê-lo às fantasias heroicas infantis, à onipotência da criança ou ao masoquismo do supereu feminino. Interpretá-lo como uma variante da fórmula — "bate-se" não impediu esse sonho de continuar a repetir-se.

Uma outra abordagem da letra, como um jogo de homofonias, permitiu decifrá-lo, reduzi-lo a um resíduo e revelar a contingência do modo singular do falante gozar de seu corpo. Isso foi possível quando pude me dar conta que durante toda a minha infância, habitava um apartamento entre a Lagoa Rodrigo de Freitas e a praia de Ipanema. Entre dois mares. Durante boa parte do ano, minha avó morava conosco. Logo, eu me encontrava entre duas mães. A língua francesa habitava incompreendida a lalíngua familiar. Tendo recuperado esse pano de fundo, constituído de um acidente geográfico e de uma contingência linguística, não foi difícil decifrar o jogo simbólico subjacente. Só me foi possível ler essa escrita fora do sentido depois que percebi a homofonia entre duas fórmulas na língua francesa: "entre deux mers e entre deux mères".

No que se refere à injunção superegoica ("não vender a alma para o diabo") cabe interpretar a inesgotável reivindicação fálica feminina. Mais além do falo, o continente negro da feminilidade habita lalíngua. A homofonia ("entre deux mères/mers") de lalíngua revela o jogo espirituoso com a letra. De um lado está a insatisfação que se manifesta como experiência extrema de divisão subjetiva e de angústia. De outro, quando podemos ler o que está escrito, revela-se o gozo com o real da letra privada de sentido. Mais além da angústia edipiana, o sonho é um efeito puro da linguagem, é um trocadilho, uma maneira divertida de saber fazer com o real sem sentido que nela se abriga.

A lei moral, o dito superegoico, o significante mestre não é - como espero demonstrar - a única incidência da escrita no inconsciente. A combinatória dos significantes puros, a lalíngua familiar, enseja outras modalidades de gozo da letra mais próximas do real, da própria vida. O sonho reduziu-se a uma escrita baseada na homofonia entre as palavras mer (mar) e mère (mãe). O referente do 
sonho é tanto "entre deux mères" (entre duas mães) como "entre deux mers" (entre dois mares). Os sintomas, quando são reduzidos à letra, revelam tanto o gozo superegoico com o significante quanto a insatisfação que aí se aloja. Mas, o objeto $a$, causa da força vital que se abriga sob o falo simbólico [Ф], a condição da vida, pulsão que nos atravessa e nos ultrapassa, também se encontra cifrada aí.

A pulsão eleva à dimensão do desejo a relação do sujeito ao seu próprio ser, esvaziado de sentido. É isso a pulsão de morte. Esta satisfação simbólica tão difícil de compreender - que nos mortifica e revivifica. A pulsão de morte tem uma afinidade de estrutura com a sublimação pulsional. A sublimação é o mistério da transubstanciação do gozo condensado nos objetos parciais numa satisfação pulsional diretamente simbólica. Ela esvazia o desejo de sua relação a um objeto determinado. O desejo fica assim reduzido apenas à pulsão, ao puro jogo de significantes. Na sublimação, enquanto um dos destinos da pulsão, o desejo equivale à letra e resiste - tal como a perversão - a toda forma de normalização, padronização, homogeneização.

$\mathrm{O}$ sintoma, reduzido às letras $\left[\mathrm{S}_{1}\right]$ e $[a]$, é feito daquilo que não se compreende. O que não se compreende, se escreve. Nem a vida, nem a morte são do campo do sentido. A morte se escreve pela lei moral, por meio do Nome-do-Pai. A vida se escreve por meio da singularidade do gozo de cada um com lalíngua. Entre deux mers e entre deux mères, homofonia discreta que escreve a satisfação que a vida proporciona, irreconhecível sob a máscara da insatisfação do desejo. Espirituosa, me dizia minha mãe, embaraçada com meu senso de humor. Reencontrar esta satisfação primeira com o meu senso de humor, me levou a abandonar o imperativo feroz de dizer a verdade, nada mais que a verdade. Pude nomear este sintoma nefasto, por meio de um jogo espirituoso. Costumo dizer que, para Lacan, os seres humanos são um "falasseres". Em minha irredutível singularidade, por uma contingência da linguagem, sou um "falassério". Quanto mais falo sério, mais faço morrer de rir. O encontro com o inconsciente real, com aquilo que está escrito no sintoma, é a única via para a queda da suposição de saber ao inconsciente e o acesso a essa felicidade inédita, ao final de uma análise, com a vida, com o simples fato de estar vivo.

\section{Referências}

Canguilhem, G. (1966). Le concept et la vie. Revue Philosophique de Louvain, 64, 193-223.

Canguilhem, G. (1970). Études de l'Histoire et de Philosophie des Sciences. Paris: Vrin.

Canguilhem, G. (1978). O normal e o patológico. Rio de Janeiro: Forense Universitária.

Canguilhem, G. (2005). Escritos sobre a medicina. Rio de Janeiro: Forense Universitária. Coleção Fundamentos do Saber (Trabalho original publicado em 1994). 


\section{CONFERÊNCIA}

Coelho dos Santos, T. (2008a). El psicoanalista es un síntoma, Mediodicho Revista de Psicoanalisis de Córdoba, 34, 107-117.

Coelho dos Santos, T. (2008b). Sinthoma: a arte de encarnar e sublimar o próprio sexo. In M. A. Coutinho \& M. Mello. (Orgs.). Saber fazer com o real (pp. 373-381). Rio de Janeiro: Companhia das Letras/UERJ.

Coelho dos Santos, T. (2009a). A interpretação analítica do sinthoma. In E. Nascimento (Org.). Revista do Curso de Especialização da UFBA (pp. 161-175). Salvador: Editora UFBA.

Coelho dos Santos, T. (2009b). Do saber exposto ao saber suposto e retorno: ensino, pesquisa e transmissão da psicanálise. Opção Lacaniana, São Paulo, 4, 83-94.

Coelho dos Santos, T. (2009c). Sobre a clínica de orientação lacaniana: dos impasses da sexuação à invenção do parceiro-sinthoma. Ágora, XII, 9-26.

Coelho dos Santos, T. (2010). Lá onde o inconsciente falassério, o real morre de rir, São Paulo, Opção Lacaniana, 58, 147-153.

Coelho dos Santos, T. (2011). Quem precisa de análise hoje? São Paulo: Bertrand Brasil.

Coelho dos Santos, T. Isso é uma ordem! ou Isso é uma ordem? Boletim da Escola Brasileira de Psicanálise, 16.

Dagonet, F. Georges Canguilhem, Philosophie de la Vie. Paris: Institut Synthélabo pour le Progrés de la Conaissance, 1997.

Freud, S. (1976a). Os chistes e sua relação com o inconsciente. In Edição Standard Brasileira das Obras Psicológicas Completas de Sigmund Freud (Vol. VIII). Rio de Janeiro: Imago. (Trabalho original publicado em 1905).

Freud, S. (1976b). Análise terminável e interminável. In Edição Standard Brasileira das Obras Psicológicas Completas de Sigmund Freud (Vol. XXIII). Rio de Janeiro: Imago. (Trabalho original publicado em 1937).

Jacob, F. (1983). A lógica da vida: uma história da hereditariedade. Rio de Janeiro: Graal.

Lacan, J. (1966). La chose freudienne. In Écrits. Paris: Seuil. (Trabalho original publicado em 1957).

Lacan, J. (1974-1975). Le séminaire. R.S.I. Paris: Éditions de 1'Association Freudienne Internationale.

Lacan, J. (1975). Le séminaire. Livre XX. Encore. Paris: Seuil. (Trabalho original publicado em 1972-1973).

Lacan, J. (1978). Le séminaire. Livre II. Le moi dans la théorie de Freud et dans la technique de la psychanalyse. Paris: Seuil. (Trabalho original publicado em 1954-1955).

Lacan, J. (1979). Le séminaire. Livre XXIV. L'insu que sait de l'une bévue s'aile l'amourre. Ornicar? Bulletin périodique du Champ Freudien. 17-18, 17-30.

Lacan, J. (1998a). O seminário. Livro V. As formações do inconsciente. Rio de Janeiro: Jorge Zahar. (Trabalho original publicado em 1957-1958).

Lacan, J. (1998b). Escritos. Rio de Janeiro: Jorge Zahar. (Trabalho original publicado em 1957).

Lacan, J. (1991). Le séminaire. Livre XVII. L'envers de la psychanalyse. Paris: Seuil. (Trabalho original publicado em 1969-1970).

Rev. Latinoam. Psicopat. Fund., São Paulo, $18(1), 17-32$, mar. 2015 
Lacan, J. (2001). Autres Écrits. Paris: Seuil.

Lacan, J. (2006). Le séminaire. Livre XVIII. D’un discours qui ne serait pas du semblante. Paris: Seuil. (Trabalho original publicado em 1971).

Laurent, E. (2009, outubro). La passe: un pari contre le sujet supposé savoir. Revista Quarto, (96), 28-35.

Marriage, V. (2002, maio). Quand c'écrit. La Cause Freudienne, 51, 35-39.

Miller, J.-A. (1987). Préface. In J. Aubert (Org.). Joyce avec Lacan. Paris: Navarin.

Miller, J.-A. (1998). Los signos del goce. Buenos Aires: Paidós.

Miller, J.-A. (1999). Elementos de biologia lacaniana. Belo Horizonte: Escola Brasileira de Psicanálise. (Trabalho original publicado em 1987).

Miller, J.-A. (2000). El banquete de los analistas. Buenos Aires: Paidós.

Miller, J.-A. (2003). Une incroyable exaltation. In J.-A. Miller (Org.). Lakant. Paris: École de la Cause Freudienne. Difusion Navarin-Seuil. Collection rue Huysmans.

Miller, J.-A. (2006, março). Pièces détachées. Curso de Orientação Lacaniana - La Cause Freudienne, 62, 79.

Miller, J.-A. (2009, outubro). Quand la cure s'arrête. Revista Quarto - École de la Cause Freudienne, 96, 10-15.

Miller, J.-A. (2010a). Extimidad. Buenos Aires: Paidós.

Miller, J.-A. (2010b). Lacan com Joyce. Correio: Revista da Escola Brasileira de Psicanálise, 65, 33-60.

Milner, J. C. (2003). De la linguistique à la linguisterie. In ECF (Org.). Lacan: l'écrit, l'image (pp. 7-25). Paris: Flammarion. Collection Champs.

Nietzsche, F. (1998). Assim falou Zaratustra. Rio de Janeiro: Civilização Brasileira.

Portocarrero, V. (2009). As ciências da vida: de Canguilhem a Foucault. Rio de Janeiro: Fiocruz.

Seynhaeve, B. (2008, dezembro). Une lettre arrive toujours à son destinataire. La Cause Freudienne, 70, 35-39.

Stevens, A. (2008, abril). Clinique de la lettre. Revista Quarto-École de la Cause Freudienne, 92, 6-14.

Vicens, A. (2008, dezembro). Témoignage. La Cause Freudienne, 70, 193-195.

\section{Resumos}

(What sort of health may be expected at the end of analysis?)

Freud defines neurosis as a way to respond to the events of life in an incorrect manner, unlike the response of the healthy man that overcomes difficulties. What form of health may we expect, then, at the end of an analysis? Can an analyst promise more than the mere replacement of neurotic misery by ordinary, banal, everyday 


\section{CONFERÊNCIA}

unhappiness? Freud argues that what is achieved through an analysis is not the sexual symptom that the subject presented in the beginning, but its reduction to an incurable rest. The analysis produces a state that never arises spontaneously in the ego and this newly created state is the difference between a person who went through analysis and one who has not.

Keywords: End of analysis, incurable rest, original state, health

(Quelle santé peut-on espérer à la fin d'une analyse?)

D'après Freud, la névrose consiste à répondre de façon incongrue aux vicissitudes de la vie, contrairement à la réponse de l'homme sain qui les surmonte. Qu'est-ce qui nous attend donc à la fin d'une analyse? L'analyste peut-il en effet promettre autre chose que le remplacement de la misère névrotique par le mal de vivre commun et banal de tous les jours? Freud affirme que ce qui est réalisé par le biais d'une analyse n'est pas le symptôme sexuel que le sujet présentait dès le début, mais sa réduction à un reste incurable. L'analyse produit un état qui ne se pose pas spontanément dans l'ego et cet état nouvellement créé constitue la différence entre une personne qui a été analysée et un autre qui ne l'a pas été.

Mots clés: Fin d'analyse, résidu incurable, état original, santé

(¿Que salud se puede esperar al fin de un análisis?)

Para Freud, la neurosis consiste en responder a los acontecimientos de la vida de forma dañina, contrario a la respuesta del hombre saludable que supera sus dificultades. Entonces, ¿qué salud se podría esperar al final de un análisis? ¿Podría un analista prometer más que la sustitución de la miseria neurótica, por la infelicidad cotidiana y ordinaria? Freud sostiene que lo que se logra a través de un análisis no es el síntoma sexual que el sujeto tenía al empezar, sino su reducción a un resto incurable. El análisis genera un estado que nunca surge espontáneamente en el ego y que este estado creado recientemente es la diferencia entre una persona que fue analizada y otra que no lo fue.

Palabras clave: Final de un análisis, resto incurable, estado inicial, salud

(Was für eine Art von Gesundheit kann man am Ende einer Analyse erwarten?)

Freud definiert die Neurose als eine verfehlte Weise, auf Lebensereignisse $z u$ reagieren, was sie von der gesunden menschlichen Reaktion unterscheidet, die diese bewältigt. Welche Art von Gesundheit können wir also am Ende einer Analyse erwarten? Kann der Analyst mehr versprechen, als den bloßen Ersatz des neurotischen Elends durch das allgemeine, banale, alltägliche Unglücklichsein? Freud argumentiert, dass das, was mit Hilfe einer Analyse erzielt wird, nicht das sexuelle Symptom ist, das sie veranlasste, sondern seine Reduktion zu einem unheilbaren Rest. Die Analyse produziert einen Zustand, der im Ich nie spontan entsteht. Dieser neu geschaffene Zustand ist 
der Unterschied zwischen einer Person, die analysiert wurde und einer anderen, die es nicht wurde.

Schlüsselwörter: Ende der Analyse, unheilbarer Rest, Originalzustand, Gesundheit

Citação/Citation: Coelho dos Santos, T. (2015, março). Que saúde esperar ao final de uma análise? Revista Latinoamericana de Psicopatologia Fundamental, 18(1), 17-32.

Editores do artigo/Editors: Manoel Tosta Berlinck e Sonia Leite

Recebido/Received: 21.10.2014/ 10.21.2014 Aceito/Accepted: 30.10.2014 / 10.30.2014

Copyright: (C) 2009 Associação Universitária de Pesquisa em Psicopatologia Fundamental/ University Association for Research in Fundamental Psychopathology. Este é um artigo de livre acesso, que permite uso irrestrito, distribuição e reprodução em qualquer meio, desde que o autor e a fonte sejam citados / This is an open-access article, which permits unrestricted use, distribution, and reproduction in any medium, provided the original authors and sources are credited.

Financiamento/Funding: A autora declara não ter sido financiada ou apoiada / The author has no support or funding to report.

Conflito de interesses/Conflict of interest: A autora declara que não há conflito de interesses / The author has no conflict of interest to declare.

\section{Tania Coelho dos Santos}

Pós-Doutorado no Département de Psychanalyse de Paris VIII (Paris, França); Professora Associada IV do PPG em Teoria Psicanalítica da Universidade Federal do Rio de Janeiro - UFRJ (Rio de Janeiro, RJ, Br); Membro da Associação Universitária de Pesquisa em Psicopatologia Fundamental - AUPPF (São Paulo, SP, Br); Psicanalista; Membro da École de la Cause Freudienne; Membro da Escola Brasileira de Psicanálise (Rio de Janeiro, RJ, Br); Membro da Associação Mundial de Psicanálise; Pesquisadora bolsista nível 1C do CNPq (Brasília, DF); Presidente do Instituto Sephora de Ensino e Pesquisa de Orientação Lacaniana (Rio de Janeiro, RJ, Br); Editora de aSEPHallus Revista de Orientação lacaniana (Rio de Janeiro, RJ, Br).

Rua Visconde de Pirajá, 318/608 - Ipanema

22410-000 Rio de Janeiro, RJ, Br

e-mail: taniacs@openlink.com.br 